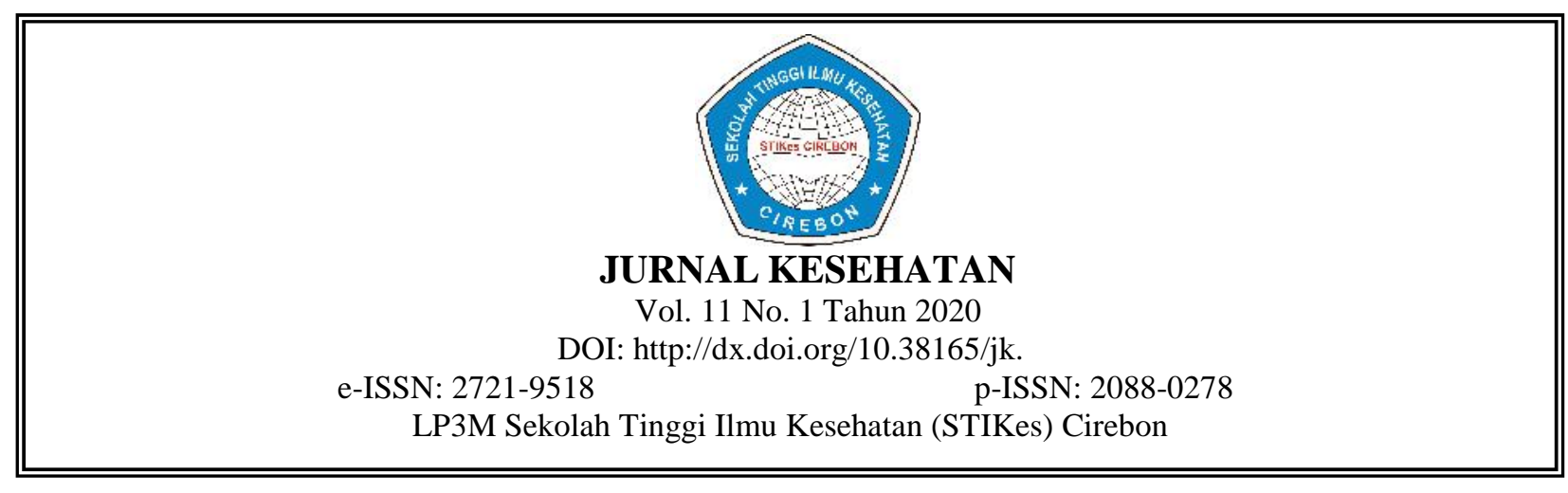

\title{
HUBUNGAN PENGETAHUAN REMAJA PUTRI TENTANG PENDEWASAAN USIA PERKAWINAN TERHADAP RISIKO PERNIKAHAN USIA DINI
}

\author{
Agi Yulia Ria Dini* \\ Program Studi Kebidanan, Sekolah Tinggi Ilmu Kesehatan Cirebon \\ agiyulia.strkeb@gmail.com \\ Vina Febriani Nurhelita** \\ Program Studi Kesehatan Masyarakat, Sekolah Tinggi Ilmu Kesehatan Cirebon
}

\begin{abstract}
Abstrak
Pernikahan dini merupakan pernikahan yang dilakukan oleh salah satu pasangan yang memiliki usia dibawah umur 17 tahun. Pernikahan belum cukup umur ini marak terjadi di Indonesia, baik di desa maupun kota. Fenomena pernikahan dini di wilayah Ciayumajakuning berkontribusi sebesar 44,67\% terhadap persentase perempuan yang pernah kawin usia dibawah 18 tahun di Jawa Barat. Perempuan yang menikah di usia dini berisiko kematian lebih tinggi akibat komplikasi saat kehamilan dan melahirkan dibandingkan perempuan dewasa. Tujuan peneliti adalah untuk mengetahui hubungan pengetahuan remaja putri tentang pendewasaan usia perkawinan terhadap resiko pernikahan usia dini di SMPN 9 Kota Cirebon Tahun 2019. Penelitian ini menggunakan desain deskriptif kuantitatif dengan metode cross sectional, populasi pada penelitian adalah remaja putri kelas 8 SMPN 9 Kota Cirebon dengan teknik accidental sampling didapatkan sampel sebanyak 32 remaja putri.Instrumen penelitian ini adalah kuesioner tertutup. Hasil analisa univariat menunjukkan bahwa pengetahuan remaja putri tentang pendewasaan usia perkawinan dengan frekuensi terbanyak adalah kategori cukup (50\%) dan tingkat risiko pernikahan usia dini pada remaja putri terbanyak adalah pada kategori cukup (40,6\%). Hasil analisa bivariat menggambarkan adanya hubungan yang berarti ( $\mathrm{p}$ value $<\alpha$ ) antara pengetahuan remaja putri tentang Pendewasaan Usia Perkawinan terhadap risiko Pernikahan Usia Dini di SMPN 9 Kota Cirebon.
\end{abstract}

Kata Kunci : Pengetahuan, Pendewasaan Usia Perkawinan, Pernikahan Usia Dini

\begin{abstract}
Early age marriage is a marriage conducted by one of the couples who have under 17 years of age. Early age marriage often occurs in Indonesia, not only in rural but also in cities. The phenomenon of early marriage in the Ciayumajakuning region contributed $44.67 \%$ to the percentage of women who had married under the age of 18 in West Java. Young lady who married at an early age the risk of death is higher as a result of complications during pregnancy and childbirth than adult women. The researcher's aim is to determine the relationship of adolescent girls' knowledge about the age of marital maturity to the risk of early age marriage at SMPN 9 Cirebon City 2019. This research uses quantitative descriptive design with cross sectional method, the population in this study was the 8th grade teenage girls of SMPN 9 Cirebon City with an accidental sampling technique obtained a sample of 32 teenage girls. The research instrument was a closed questionnaire. Univariate analysis results show that the knowledge of young women about the age of marriage with the highest frequency is moderatecategory (50\%) and the level of risk of early marriage in young girls is in the moderate category (40.6\%). Bivariat analysis results show that there is a significant relationship (p value $<a)$ between the knowledge of teenage girls about marital maturity to the risk of early age Marriage at SMPN 9 Cirebon City.
\end{abstract}

Keywords: Knowledge, Maturing Age of Marriage, Early Age Marriage

JURNAL KESEHATAN Vol. 11 No. 1 Tahun 2020 |50 


\section{PENDAHULUAN}

Pernikahan adalah upacara pengikatan janji yang dirayakan atau dilaksanakan oleh dua orang dengan maksud meresmikan ikatan perkawinan secara norma agama, norma hukum, dan norma sosial. Upacara pernikahan memiliki banyak ragam dan variasi menurut tradisi suku bangsa, agama, budaya, maupun kelas sosial. Penggunaan adat atau aturan tertentu kadang-kadang berkaitan dengan aturan atau hukum agama tertentu pula. Adapun pengertian pernikahan dini adalah pernikahan yang dilakukan oleh salah satu pasangan yang memiliki usia dibawah umur 17 tahun. Jika melangsungkan pernikahan dapat dikatakan sebagai pernikahan usia dini. ${ }^{1}$ Perkawinan pada remaja masih menjadi fenomena yang mengkhawatirkan di dunia. Deklarasi Universal HAM, Konvensi Hak Anak, CEDAW (Badan PPB yang menangani kasus kekerasan terhadap perempuan), telah menolak perkawinan di usia muda. CEDAW terutama merekomendasikan umur individu harus di atas 18 tahun sebelum melakukan pernikahan Remaja perempuan menjadi kelompok yang paling terkena dampak. Setidaknya terdapat 51 juta remaja perempuan berumur $15-19$ tahun yang telah menikah di seluruh dunia. ${ }^{2}$ Pernikahan remaja atau belum cukup umur juga ini marak terjadi di Indonesia, tidak hanya di desa melainkan juga di kota. Dalam undang-undang pernikahan disebutkan bahwa pernikahan yang ideal adalah laki-laki berusia 25 tahun dan perempuan berusia 21 tahun, pada usia tersebut seseorang yang melakukan pernikahan sudah memasuki usia dewasa, sehingga sudah mampu memikul tanggung jawab dan perannya masing-masing, baik sebagai suami maupun sebagai istri. Namun, dalam realitanya banyak terjadi pernikahan dini, yaitu pernikahan yang terjadi antara laki-laki dan perempuan yang belum dewasa dan matang berdasarkan undangundang maupun dalam perpektif psikologis. ${ }^{1}$

Perkawinan anak uisa $<18$ tahun masih tinggi di Indonesia. Sekitar 1 dari 4 anak perempuan menikah sebelum berusia 18 tahun. Perempuan yang menikah di usia anak berisiko kematian lebih tinggi akibat komplikasi saat kehamilan dan melahirkan dibandingkan perempuan dewasa. ${ }^{2}$ Undang-undang pernikahan menyebutkan bahwa pernikahan yang ideal adalah laki-laki berusia 25 tahun dan perempuan berusia 21 tahun, pada usia tersebut seseorang yang melakukan pernikahan sudah memasuki usia dewasa, sehingga sudah mampu memikul tanggung jawab dan perannya masing-masing, baik sebagai suami maupun sebagai istri. Namun, dalam realitanya banyak terjadi pernikahan dini, yaitu pernikahan yang terjadi antara laki-laki dan perempuan yang belum dewasa dan matang berdasarkan undang-undang maupun dalam perpektif psikologis. ${ }^{2}$

Peranan Badan Kependudukan dan Keluarga Berencana Nasional (BKKBN) dalam Perencanaan Usia Pernikahan (PUP) adalah pelibatan remaja dalam kependudukan dan keluarga berencana sebagai upaya pemenuhan hak-hak kesehatan reproduksi dan seksual, remaja merupakan sasaran program Kependudukan Keluarga Berencana dan Pembangunan Keluarga (KKBPK), dalam upaya menurunkan kelahiran total melalui penurunan kelahiran di kelompok remaja (15 - 19 tahun) dengan upaya pendewasaan usia perkawinan (meningkatkan usia kawin pertama perempuan), dalam upaya Pembinaan Ketahanan dan Kesejahteraan Keluarga untuk mendukung keluarga agar dapat melaksanakan fungsi keluarga secara optimal dengan cara peningkatan kualitas remaja dengan pemberian akses informasi, pendidikan, konseling dan pelayanan tentang kehidupan berkeluarga. ${ }^{3}$

Indonesia merupakan negara dengan angka pernikahan dini tertinggi ke-2 di ASEAN setelah Kamboja. Hampir 10\% anak perempuan menjadi ibu pada usia 16 tahun di negara miskin dan berkembang dengan angka tertinggi salah satunya di Asia Tenggara. Berdasarkan Riset Kesehatan Dasar (RISKESDAS) pada tahun 2010, secara umum usia rata-rata perkawinan pertama pada usia 20 tahun, namun berdasarkan kelompok umur perkawinan pertama menunjukkan bahwa terdapat perkawinan pada usia muda yaitu 10-19 tahun sebesar 46,7\% di mana 4,8\% diantaranya terjadi pada usia 10-14 tahun dan 41,9\% terjadi pada usia 15-19 tahun.4 Provinsi Jawa Barat merupakan salah satu provinsi yang memiliki persentase perkawinan usia muda tertinggi di Indonesia, yaitu 7,5\% terjadi pada usia 10-14 tahun dan 50,2\% pada usia 15-19 tahun. ${ }^{4}$

Badan Kependudukan dan Keluarga Berencana Nasional (BKKBN), mengungkapkan hasil survei indikator Kinerja Rencana Pembangunan Jangka Menengah Nasional (RPJM) 2015, dalam rangka menekan angka pernikahan usia dini. Dalam survei tersebut diketahui, sebanyak 19,2\% respon remaja wanita merencanakan menikah di bawah umur 22 tahun, sedangkan untuk remaja 
pria sebesar 46,2\% merencanakan menikah di umur 20-25 tahun. Peranan Badan Kependudukan dan Keluarga Berencana Nasional (BKKBN) dalam Perencanaan Usia Pernikahan (PUP) adalah pelibatan remaja dalam kependudukan dan keluarga berencana sebagai upaya pemenuhan hak-hak kesehatan reproduksi dan seksual, remaja merupakan sasaran program Kependudukan Keluarga Berencana dan Pembangunan Keluarga (KKBPK), dalam upaya menurunkan kelahiran total melalui penurunan kelahiran di kelompok remaja (15 - 19 tahun) dengan upaya pendewasaan usia perkawinan (meningkatkan usia kawin pertama perempuan), dalam upaya Pembinaan Ketahanan dan Kesejahteraan Keluarga untuk mendukung keluarga agar dapat melaksanakan fungsi keluarga secara optimal dengan cara peningkatan kualitas remaja dengan pemberian akses informasi, pendidikan, konseling dan pelayanan tentang kehidupan berkeluarga. ${ }^{5}$

Survei Sosial Ekonomi Nasional (Susenas) tahun 2017 menunjukan data bahwa di Provinsi Jawa Barat ada $17,28 \%$ pernikahan anak usia $<16$ tahun, dan ada 23,43\% pernikahan anak usia $<17-18$ tahun. Pernikahan dini yang masih tinggi bukan masalah sederhana. Di tengah peringatan Hari Anak Nasional (HAN) 2018, pernikahan anak cukup mengkhawatirkan. Terlebih dampaknya terhadap masa depan anak. Di Provinsi Jawa Barat tahun 2018 presentase pernikahan dini anak usia kurang dari 15 tahun sebanyak 7,5\% dan usia antara 15-19 tahun sebanyak 52,1\%. Komposisi ini menempatkan Jawa Barat menduduki peringkat kedua nasional. ${ }^{6}$

Fenomena pernikahan dini di wilayah Ciayumajakuning cukup tinggi. Secara rata-rata untuk wilayah Ciayumajakuning berkontribusi sebesar 44,67\% terhadap persentase perempuan yang pernah kawin usia dibawah 18 tahun di Jawa Barat. Dari sembilan kota yang ada di Jawa Barat, persentase perempuan yang pernah kawin di usia 18 tahun ke bawah paling banyak di Kota Banjar dan Kota Cirebon menduduki posisi ke empat dengan presentase $28,74 \%{ }^{5}$

Badan Pemberdayaan Masyarakat, Pemberdayaan Perempuan dan Keluarga Berencana (BPMPPKB) Kota Cirebon mengakui bahwa fenomena pasangan menikah usia muda di Kota Cirebon meningkat. Data BPMPPKB menyebutkan, pada 2013 jumlah pasangan usia subur yang menikah dini mencapai 299 pasangan, rata-rata usianya antara 15 hingga 18 tahun. Jumlah tersebut meningkat pada 2014 yang mencapai 388 pasangan. Secara menyeluruh, data pasangan usia subur yang menikah di tahun 2015 mencapai 40.881 pasangan. BPMPPKB menargetkan tahun 2018 angka pernikahan usia dini berkurang hingga 46 pasangan. ${ }^{7}$

Berdasarkan hasil dari studi pendahuluan di SMPN 9 Kota Cirebon. Pengetahuan remaja putri tentang pendewasaan usia perkawinan dan pernikahan usia dini dari 18 siswi yang ditanya, mereka mengatakan tidak mengetahui tentang pendewasaan usia perkawinan. Alasannya karena belum pernah ada sosialisasi, belum pernah mendengar maupun membacanya, tetapi ada 7 remaja putri yang mengatakan pernah mendengar sekilas tentang pernikahan usia dini. Pihak sekolah mengatakan masih ada siswa nya yang setelah lulus tidak melanjutkan sekolah dan langsung menikah, alasannya karena faktor ekonomi.

Pengenalan tentang pentingnya pendewasaan usia perkawinan sejak remaja diharapkan dapat membuka cara pandang remaja masa kini dan dapat mengurangi pernikahan usia dini. Dari uraian di atas, penulis tertarik untuk melakukan penelitian mengenai hubungan pengetahuan remaja putri tentang pendewasaan usia perkawinan terhadap resiko pernikahan usia dini di SMPN 9 Kota Cirebon tahun 2019.

\section{METODE PENELITIAN}

Penelitian ini menggunakan rancangan penelitian analitik dengan metode cross sectional yaitu dengan menganalisa Hubungan Pengetahuan Remaja Putri Tentang Pendewasaan Usia Perkawinan Terhadap Resiko Pernikahan Usia Dini di SMPN 9 Kota Cirebon. Untuk mempelajari korelasi antara variabel independen dan variabel dependen dengan cara pendekatan yang sama. Populasi adalah keseluruhan subjek penelitian atau objek yang diteliti. Populasi dalam penelitian ini adalah seluruh remaja putri kelas 8 A-I di SMPN 9 Kota Cirebon berjumlah 103 orang. Dalam penelitian ini cara pengambilan sampel menggunakan Accidental Sampling, yaitu pengambilan sampel secara (accidental). Accidental Sampling adalah teknik penentuan sampel berdasarkan kebetulan, yaitu 
responden bertemu dengan peneliti dapat digunakan sebagai sampel. Sehingga didapatkan sampel dengan jumlah sampel 32 orang remaja putri.

Teknik pengumpulan data dalam penelitian ini menggunakan data primer dimana peneliti berbaur langsung dengan responden dalam pengisian kuesioner. Sebelum pengisian kuesioner, hal utama yang dilakukan adalah informed consent sebagai bukti persetujuan atas kesediaan responden. Adapun cara pengambilan instrumen yaitu dengan cara kuesioner. Kuesioner yaitu teknik pengumpulan data dengan cara menyebarkan dan menarik kembali pertanyaan tertulis yang harus diteliti atau dijawab oleh sejumlah responden, guna memperoleh keterangan yang diperlukan dengan masalah yang diteliti. Dan dalam penentuan skala menggunakan skala bentuk pertanyaan tertutup (Closed Ended), dengan variasi Dichotomous Choice yaitu dalam pertanyaan ini hanya disediakan dua alternatif jawaban.

Analisa univariat bertujuan untuk menjelaskan atau mendeskripsikan karakteristik masingmasing variabel yang diteliti. Data merupakan data primer yang dikumpulkan melalui pengisian kuesioner. Analisa univariat dalam penelitian ini adalah pengetahuan remaja putri tentang pendewasaan usia perkawinan dan pengetahuan remaja putri tentang risiko pernikahan usia dini data disajikan dalam bentuk frekuensi dan presentase. Analisis bivariat yang dilakukan terhadap dua variabel yang berhubungan atau berkorelasi. Alat yang digunakan dalam penelitian ini adalah lembar kuesioner.

\section{HASIL PENELITIAN}

\section{Pengetahuan Remaja Putri Tentang Pendewasaan Usia Perkawinan}

Berdasarkan hasil analisa data pengetahuan remaja putri tentang pendewasaan usia perkawinan di SMPN 9 Kota Cirebon tahun 2019 terhadap 32 responden diperoleh hasil yang disajikan dalam tabel distribusi dibawah ini:

Tabel 1. Distribusi Frekuensi Tingkat Pengetahuan Remaja Putri tentang Pendewasaan Usia Perkawinan Di SMPN 9 Kota Cirebon Tahun 2019

\begin{tabular}{lccc}
\hline & Kategori & $\mathrm{n}$ & Persentase $(\%)$ \\
\hline Baik & 5 & 15,6 \\
Cukup & 16 & 50 \\
Kurang & 11 & 34,4 \\
\hline Total & 32 & 100 \\
\hline
\end{tabular}

Berdasarkan tabel 1 dapat diketahui bahwa dari 32 orang siswi putri SMPN 9 Kota Cirebon, sebagian besar pengetahuan tentang pendewasaan usia perkawinan cukup yaitu sebanyak 16 responden $(50 \%)$, sedangkan 11 responden $(34,4 \%)$ pengetahuannya kurang dan 5 responden $(15,6 \%)$ pengetahuannya baik.

\section{Variabel Pengetahuan Remaja Putri Tentang Risiko Pernikahan Usia Dini}

Berdasarkan hasil analisa data resiko pernikahan usia dini di SMPN 9 Kota Cirebon tahun 2019 terhadap 32 responden diperoleh hasil yang disajikan dalam tabel distribusi dibawah ini:

Tabel 2. Distribusi Frekuensi Tingkat Risiko Pernikahan Usia Dini di SMPN 9 Kota Cirebon tahun 2019

\begin{tabular}{lccc}
\hline & Kategori & $\mathrm{n}$ & Persentase $(\%)$ \\
\hline Baik & 8 & 25 \\
Cukup & 13 & 40,6 \\
Kurang & 11 & 34,4 \\
\hline Total & 32 & 100 \\
\hline
\end{tabular}

Berdasarkan tabel 2 dapat diketahui bahwa dari 32 orang siswi putri SMPN 9 Kota Cirebon, sebagian besar pengetahuan terhadap risiko pernikahan usia dini cukup yaitu sebanyak 13 responden $(40,6 \%)$, sedangkan 11 responden pengetahuannya kurang $(34,4 \%)$ dan 8 responden (25\%) pengetahuannya baik. 


\section{Hubungan Antara Pengetahuan Remaja Putri TentangPendewasaan Usia Perkawinan Terhadap Risiko Pernikahan Usia Dini di SMPN 9 Kota Cirebon Tahun 2019}

Tujuan penelitian ini adalah mengetahui hubungan pengetahuan remaja putri tentang pendewasaan usia perkawinan terhadap risiko pernikahan usia dini di SMPN 9 Kota Cirebon Tahun 2019. Pengujian hipotesis penelitian ini menggunakan uji spearmans diperoleh hasil sebagai berikut:

Tabel 3. Hubungan Antara Pengetahuan Remaja Putri Tentang Pendewasaan Usia Perkawinan Terhadap Risiko Pernikahan Usia Dini di SMPN 9 Kota Cirebon Tahun 2019

\begin{tabular}{lrrrrl}
\hline \multirow{2}{*}{ Kategori } & \multicolumn{4}{c}{ Pengetahuan } & \multirow{2}{*}{ P Value } \\
\cline { 2 - 5 } & \multicolumn{2}{c}{ PUP } & \multicolumn{2}{c}{ PUD } & \\
\cline { 2 - 5 } & $\mathrm{n}$ & $\%$ & $\mathrm{n}$ & $\%$ & 0.003 \\
Baik & 5 & 15,6 & 8 & 25 & \\
Kukup & 16 & 50 & 13 & 40,6 & \\
\hline Jumlah & 11 & 34,4 & 11 & 34,4 & \\
\hline
\end{tabular}

Berdasarkan tabel 3 hasil uji bivariat dengan menggunakan uji spearman rank correlation menunjukkan nilai $\mathrm{p}$ lebih kecil dari pada a yang digunakan yaitu $(0,05)$ atau $0,003<0,05$ sehingga H0 ditolak. Artinya terdapat hubungan antara pengetahuan remaja putri tentang pendewasaan usia perkawinan terhadap risiko pernikahan usia dini di SMP Negeri 9 Kota Cirebon Tahun 2019.

\section{PEMBAHASAN}

\section{Pengetahuan tentang Pendewasaan Usia Perkawinan}

Pendewasaan berasal dari kata dewasa. Kata dewasa berasal dari kata latin adolensence yang berarti tumbuh atau tumbuh menjadi dewasa. Istilah adolensence mempunyai arti yang lebih luas lagi yang mencakup kematangan mental, emosional, sosial dan fisik, dalam kata lain dikatakan bahwa masa remaja adalah masa peralihan dari anak-anak menjadi dewasa dengan rentan usia antara 12-22 tahun, di mana pada masa tersebut terjadi proses pematangan baik itu pematangan fisik maupun pisikologis. Istilah dewasa menggambarkan segala organisme yang telah matang, tapi lazimnya merujuk pada manusia: orang yang bukan lagi anak-anak dan telah menjadi pria atau wanita dewasa. Pengertian dewasa sendiri sering diidentikan pada sebuah tahapan. Seperti masa dewasan merupakan salah satu tahapan perkembangan manusia. Pada masa dewasa ini individu dianggap telah siap menghadapi suatu perkawinan, namun perkawinan bukanlah suatu hal yang mudah karena banyak konsekuensi yang harus dihadapi sebagai suatu bentuk tahapan kehidupan baru sebagai manusia dewasa. ${ }^{8}$

Pendewasaan Usia Perkawinan (PUP) merupakan upaya untuk meningkatkan usia pada saat perkawinan pertama yakni usia minimal 20 tahun bagi perempuan dan 25 tahun bagi laki-laki. Sedangkan hak kebebasan dan keamanan dalam kehidupan reproduksi merupakan hak reproduksi remaja yang melekat sejak manusia lahir dan dilindungi keberadaannya, sehingga larangan atau pembatasan terhadap hak reproduksi berarti pengekangan pada hak asasi manusia itu sendiri. Titik tolak kongret kedua pengertian ini berasal dari pemahaman bahwa PUP bukan sekedar penundaan usia perkawinan pada batas usia tertentu tetapi juga mengusahakan agar terjadi kehamilan pertama pada usia yang cukup dewasa atau matang secara reproduksi dan psikologi untuk mengalami kehamilan. Bahkan harus diusahakan apabila seseorang gagal mendewasakan usia perkawinannya, maka penundaan dalam kehamilan dan kelahiran anak pertama harus dilakukan. Dalam istilah KIE dikenal sebagai anjuran untuk mengubah bulan madu menjadi tahun madu. Dimana pasangan usia muda menunda beberapa tahun sampai dengan usia yang siap untuk mengalami kehamilan. Pendewasaan usia perkawinan merupakan bagian dari program Keluarga Berencana Nasional. Program PUP memberikan dampak pada peningkatan umur kawin pertama yang pada gilirannya akan menurunkan Total Fertility Rate (TFR). ${ }^{9}$ 
Program pendewasaan usia perkawinan didalamnya terdapat kerangka berupa Program Pendewasaan Usia Kawin dan Perencanaan Keluarga. Kerangka ini terdiri dari dua masa reproduksi, yaitu masa menunda perkawinan dan kehamilan serta masa menjarangkan kehamilan. Kelahiran anak yang tepat merupakan kelahiran yang dilakukan oleh seorang ibu yang telah berusia 20 tahun. Seorang ibu dibawah usia 20 tahun yang melahirkan anak dapat mempengaruhi kesehatan, baik pada ibu maupun anak yang dilahirkan. Oleh karenanya dianjurkan pada seorang wanita yang belum berusia 20 tahun untuk menunda perkawinannya dan bila sudah terlanjur menjadi pasangan suami istri pada usia dibawah 20 tahun, maka disarankan melakukan tahun madu berupa penundanan kehamilan dengan menggunakan alat kontrasepsi. ${ }^{9}$

Alasan medis secara objektif dalam penundaan usia perkawinan dan kehamilan pertama bagi wanita yang belum mencapai usia 20 tahun diantaranya diesbabkan belum berkembangnya kondisi rahim dan panggul secara optimal yang dapat mengakibatkan risiko kesakitan dan kematian pada masa kehamilan, persalinan dan nifas serta berdampak pula pada bayinya, selain itu terdapat kemungkinan munculnya risiko medik serta penyulit-penyulit pada masa kehamilan, persalinan dan nifas lainnya. ${ }^{9}$

Kerangka kedua pada Program Pendewasaan Usia Kawin dan Perencanaan Keluarga adalah masa menjarangkan kehamilan. Menjarangkan kehamilan yang dimaksud adalah menjaga jarak ideal pada setiap kelahiran anak, dimana jarak kelahiran pada setiap anak tidak boleh kurang dari 2 tahun. Masa menjarangkan kehamilan terjadi pada periode Perempuan Usia Subur (PUS) berada pada umur 20-35 tahun. Secara empirik perempuan pada usia subur sebaiknya melahirkan pada periode umur 20-35 tahun, sehingga tidak terjadi risiko-risiko medik yang diuraikan diatas. Periode 15 tahun (usia 20-35 tahun) pada wanita dianjurkan untuk memiliki 2 anak. Sehingga antara dua kelahiran bagi PUS kelompok ini adalah sekitar 7-8 tahun yang merupakan jarak ideal. Patokan dari jarak ideal kelahiran adalah jangan terjadi dua balita dalam kurun waktu 5 tahun. Alat kontrasepsi dapat digunakan untuk menjarangkan kehamilan. Pemakaian alat kontrasepsi pada tahap ini dilaksanakan untuk menjarangkan kelahiran agar ibu dapat menyusui anaknya dengan cukup banyak dan lama. ${ }^{9}$

Hasil penelitian menunjukkan bahwa tingkat pengetahuan responden tentang Pendewasaan Usia Perkawinan didapatkan hasil baik yaitu sebanyak 16 responden (50\%), kurang sebanyak 11 responden $(34,4 \%)$, dan 5 responden $(15,6 \%)$ pengetahuannya baik. Pengetahuan responden tentunya sangat dipengaruhi oleh berbagai informasi yang didapatkan oleh responden itu sendiri. Seperti halnya dengan pengetahuan yang merupakan hasil tahu dari manusia, dan ini terjadi setelah orang melakukan pengindraan terhadap suatu objek tertentu. Pengindraan terjadi melalui panca indra manusia, yakni indra penglihatan, pendengaran, penciuman rasa dan raba. Sebagai pengetahuan diperoleh dari mata. ${ }^{10}$

\section{Pengetahuan tentang Risiko Pernikahan Usia Dini}

Pernikahan usia remaja merupakan pernikahan yang dilakukan oleh seseorang yang pada hakekatnya kurang mempunyai persiapan atau kematangan baik secara biologis, psikologis maupun sosial ekonomi. Masa remaja merupakan masa peralihan manusia dari anak-anak menuju dewasa. Remaja merupakan masa peralihan antaramasa anak dan masa dewasa yang berjalan antara umur 11 tahun sampai 21 tahun. Dalam masa remaja terjadi peralihan dari masa kanak- kanak ke masa dewasa dimana terjadi perubahan fisik, mental dan psikososial yang cepat dan berdampak sebagai aspek kehidupan selanjutnya. Gerakan pendewasaan usia perkawianan (PUP) merupakan gerakan untuk meningkatkan rata-rata usia kawin pertama wanita secara ideal, perempuan 20 tahun dan laki-laki 25 tahun. ${ }^{9}$ Risiko yang ditimbulkan dari pernikahan usia dini antara lain, anemia saat kehamilan, keguguran, persalinan lama, prematuritas, KDRT, perceraian dan meningkatnya jumlah penduduk serta angka kemiskinan. Dari sudut pandang medis, pernikahan dini merupakan pernikahan yang dilakukan sebelum kedua calon pengantin belum mencapai kematangan fisik untuk menikah. Terutama bagi perempuan dimana organ-organ reproduksinya belum siap untuk hamil dan melahirkan sehingga sangat berisiko dari segi kesehatan. Walaupun ketika seorang perempuan telah mengalami menstruasi berarti ia sudah bisa hamil, akan tetapi pertumbuhannya belum sempurna 
seperti tulang panggul sehingga sangat berisiko ketika melahirkan. Pernikahan pada usia muda dapat meningkatkan risiko terjadinya keguguran, obstetric fistula, kanker leher rahim, dan berbagai masalah lainnya. Kehamilan pada perempuan dengan usia yang sangat muda merupakan masalah yang signifikan. Kehamilan di usia yang sangat muda berkorelasi dengan angka kesakitan dan kematian ibu. Remaja menghadapi risiko lebih tinggi yaitu komplikasi dan kematian akibat kehamilan daripada perempuan yang lebih tua. Risiko angka kematian perempuan yang hamil dan bersalin pada kelompok usia 10 - 14 tahun meningkat lima kali lipat dibandingkan kelompok usia 20-24 tahun, sementara risiko ini meningkat dua kali lipat pada kelompok usia 15-19 tahun. Komplikasi yang dapat terjadi pada kehamilan usia muda diantaranya anemia, HIV (Human Immunodeficiency Virus) dan penyakit menular seksual lainnya, perdarahan pasca salin, dan gangguan mental seperti depresi yang berhubungan dengan kehamilan remaja. ${ }^{9}$ Sedangkan jika dilihat dari segi mental dan sosial, pada usia tersebut kedua calon pengantin atau pasangan suami istri belum memiliki kematangan secara psikologis dan cara berpikir. Kehidupan pernikahan memiliki banyak problema yang harus dihadapi dengan cara berpikir yang dewasa dan kematangan emosi. $^{2}$

Trauma perkawinan dapat menjadi dampak pada seseorang yang melakukan pernikahan belum cukup usia atau dibawah umur. Trauma ini diakibatkan oleh ketidaksiapan mental dalam menjalankan tugas-tugas perkembangan yang muncul setelah adanya perkawinan, sementara hal ini tidak didukung dengan kemampuan dan kematangan diri yang dimiliki. Salah satu tugas perkembangan selama masa remaja dilihat dalam aspek perkembangan sosial adalah menyelesaikan krisis identitas, sehingga diharapkan terbentuk identitas dri yang stabil pada masa remaja, sehingga akan memperoleh suatu pandangan yang jelas tentang dirinya. Pada konteks remaja yang melakukan perkawinan, proses identifikasi diri remaja yang ideal sulit untuk dicapai. Hal ini karena pada konteks perkawinan seorang individu remaja akan dipandang sebagai orang dewasa bahkan sebagai calon orangtua. Pandangan ini menimbulkan efek kebingunan terhadap pelaku perkawinan dan kesulitan mengidentifikasikan dirinya dalam masyarakat. Krisis yang harusnya diselesaikan pada pencarian identitas diri akan mengalami kegagalan, sehingga membahayakan masa depan remaja. Perkembangan sosial-emosional remaja memiliki peran untuk memenuhi tugas-tugas perkembangannya dengan baik. Tugas-tugas perkembangan remaja ini harus dipenuhi terlebih dahulu sebelum pernikahan untuk membentuk pondasi yang bertujuan mencapai kesejahteraan psikologis dan kebahagiaan individu.Dampak lain yang dirasakan oleh anak perempuan yang kawin di usia muda adalah adanya ancaman kesehatan mental. Anak perempuan seringkali mengalami stres ketika meninggalkan keluarganya dan bertanggung jawab atas keluarganya sendiri. ${ }^{11}$

Masa remaja merupakan masa dimana periode tersebut mempunyai tingkat fertilitas (kesuburan) yang tinggi, sehingga perkawinan usia muda kurang mendukung program pembangunan di bidang kesejahteraan. Dari segi kelangsungan rumah tangga, perkawinan usia muda menjadi sangat rawan dan belum stabil, tingkat kemandiriannya masih rendah serta menyebabkan banyak terjadinya perceraian. ${ }^{9}$

Hasil penelitian menunjukan bahwa pengetahuan remaja putri terhadap risiko Perkawinan Usia Dini didapatkan pengetahuannya cukup yaitu sebanyak 13 responden (40,6\%), 11 responden pengetahuannya kurang $(34,4 \%)$, dan 8 responden $(25 \%)$ pengetahuannya baik. Data tersebut menunjukkan bahwa sebagian besar responden pengetahuannya cukup, tentang Risiko Perkawinan Usia Dini dan hanya sebagian kecil saja responden yang tahu. Hal ini tentunya disebabkan oleh beberapa faktor. Faktor yang mempengaruhi pengetahuan meliputi pendidikan, informasi/media masa, sosial budaya dan ekonomi, lingkungan, pengalaman, usia. Faktor informasi, lingkungan dan sikap untuk mencari informasi tersebut. Serta faktor konsentrasi dalam pengisian kuisioner yang dilakukan responden, yang sangat berpengtaruh terhadap hasil. Informasi mempengaruhi pengetahuan seseorang, jika sering mendapatkan informasi tentang suatu pembelajaran maka akan menambah pengetahuan dan wawasannya. Sedangkan seseorang yang tidak sering. Di Indonesia saat ini sudah mulai di berikan informasi terkait kesehatan reproduksi remaja di sekolah-sekolah yang didalam nya juga terdapat informasi mengenai risiko kehamilan remaja, oleh karena nya hasil analisa univariat menunjukan bahwa sebagian besar responden memiliki pengetahuan yang cukup, 
ditambah lagi dengan mudah nya remaja mengakses internet yang didalamnya terdapat informasi informasi terkait pernikahan remaja dan kesehatan reproduksi pada umumnya.

\section{Hubungan Antara Pengetahuan Responden tentang PUP dengan Risiko PUD}

Hasil penelitian mengenai tingkat pengetahuan tentang PUP (Pendewasaan Usia Perkawinan) menunjukkan bahwa faktor pengetahuan mempunyai hubungan terhadap risiko PUD (Pernikahan Usia Dini ) di SMPN 9 Kota Cirebon tahun 2019. Selain itu dari analisis data dengan SPSS for Windows versi 17.00 menggunakan uji spearman rank corelation dengan taraf signifikansi $(\alpha) 0,05$ atau tingkat kepercayaan $95 \%$, diperoleh nilai p lebih kecil dari pada a yang digunakan yaitu $(0,05)$ atau $0,003<0,05$. Hal ini berarti terdapat hubungan secara positif antara pengetahuan remaja putri tentang pendewasaan usia perkawinan terhadap risiko pernikahan usia dini di SMP Negeri 9 Kota Cirebon, Ho ditolak karena nilai sig <0,05.

Tujuan program pendewasaan usia perkawinan adalah memberikan pengertian dan kesadaran kepada remaja agar didalam merencanakan keluarga, mereka dapat mempertimbangkan berbagai aspek berkaitan dengan kehidupan berkeluarga, kesiapan fisik, mental, emosional, pendidikan, sosial, ekonomi serta menentukan jumlah dan jarak kelahiran. Tujuan PUP seperti ini berimplikasi pada perlunya peningkatan usia kawin yang lebih dewasa. Program Pendewasaan Usia Kawin dan Perencanaan Keluarga merupakan kerangka dari program pendewasaan usia perkawinan. Kerangka ini terdiri dari dua masa reproduksi, yaitu masa menunda perkawinan dan kehamilan dan masa menjarangkan kehamilan. ${ }^{9}$

Pengetahuan merupakan respon seseorang terhadap stimulus atau rangsangan yang masih bersifat terselubung, sedangkan tindakan nyata seseorang yang belum otomatis terwujud sebagai respons terhadap stimulus merupakan overt behaviour. Pengetahuan itu sendiri dipengaruhi oleh tingkat pendidikan, dimana pengetahuan kesehatan akan berpengaruh kepada perilaku sebagai hasil jangka menengah (intermediate impact). pengetahuan merupakan faktor kekuatan terjadinya perubahan sikap. Pengetahuan dan sikap akan menjadi landasan terhadap pembentukan remaja sehingga dalam diri seseorang idealnya ada keselarasan yang terjadi antara sikap dan pengetahuan. Dimana sikap terbentuk setelah terjadi proses tahu terlebih dahulu. ${ }^{12}$

Penelitian yang mengkaji usia perkawinan dalam perspektif filsafat hukum dan kontribusinya bagi pengembangan hukum perkawinan indonesia menemukan bahwa ketentuan usia perkawinan sebagaimana termaktub dalam UUP mengidap persoalan yang tidak mudah diselesaikan. Indikasi problematis usia perkawinan yang paling menonjol muncul ketika dihadapkan pada pasal 7 ayat (2) tentang "dispensasi kawin" yang mana wewenang yuridis untuk keperluan itu diberikan kepada pengadilan dinilai mengurangi sakralitas perkawinan. ${ }^{10}$ Penelitian ini membahas pembedaan usia perkawinan dalam UUP dianggap membakukan peran dan status antara suami-istri dalam pola relasi yang tidak seimbang, dan pada akhirnya mendiskriminasikan wanita. Oleh karena itu, kesetaraan dari segi usia ideal adalah masing-masing calon pengantin berada pada usia 21 tahun, dengan pertimbangan psikologis, sosiologis, dan kesehatan. Idealisasi usia perkawinan pada usia 21 tahun ini merupakan bagian yang sangat signifikan dalam merekonstruksi pemikiran Hukum Perkawinan di Indonesia. Sebagai bentuk kontribusi konseptual, filsafat hukum memandang usia perkawinan ideal sebagai aspek genuine dalam membangun rumah tangga, sebagai contoh faktor kematangan psikologis dapat mengeliminasi kecenderungan konflik (broken home). Pengaturan hukum perkawinan dengan ketentuan usia 21 tahun akan menjamin terpeliharanya sumber daya manusia. Tegasnya adalah menikah pada usia 21 tahun akan terbangun keluarga sehat yang akan melahirkan generasi yang berkualitas, tidak hanya dari segi lahiriah tapi juga segi batiniah. ${ }^{10}$

Pengetahuan merupakan domain yang sangat penting untuk terbentuknya tindakan (over behavior) pada seseorang. Berdasarkan pengalaman dan penelitian, ternyata perilaku yang didasari oleh pengetahuan akan lebih berlangsung lama daripada peilaku yang tidak didasari oleh pengetahuan. Tingkat pengetahuan seseorang memengaruhi perilaku yang dilakukannya karena sebelum seseorang tahu terlebih dahulu apa arti dan manfaat suatu perilaku bagi dirinya maupun keluarganya ia akan mengadopsi perilaku tersebut. ${ }^{14}$ Reponden yang aktif akan cenderung memiliki wawasan yang luas serta mudah dalam menerima informasi dari luar, seperti dari televisi, koran, 
dan majalah. Pada tingkat pendidikan menengah, seseorang telah mempunyai wawasan dan tingkat pengetahuan yang cukup baik sehingga terbuka terhadap hal-hal baru, termasuk juga responden untuk berusaha mengetahui program pendewasaan usia perkawinan merupakan upaya untuk mencegah risiko yang ditimbulkan dari pernikahan usia dini. Hal ini menunjukkan bahwa tingkat pendidikan berhubungan dengan sikap remaja putri. Oleh karena itu responden dengan latar belakang berpendidikan SMP menumbuhkan cara pandang untuk mencegah terjadinya risiko dari pernikahan usia dini, dan kurangnya tingkat pengetahuan responden tentang risiko pernikahan usia dini, serta bagaimana mencegahnya dapat menyebabkan peningkatan kejadian remaja menikah usia dini. Hal ini juga sejalan dengan penelitian yang dilakukan oleh Stang, terdapat hubungan yang bermakna antara pengetahuan seseorang yang melakukan pernikahn dini dan yang tidak melakukan pernikahan dini. Hasil penelitian tersebut menunjukkan bahwa responden yang memiliki pengetahuan yang rendah lebih banyak melakukan pernikahan dini karena pada umumnya belum mengetahu tentang batasan usia pernikahan dan dampak negatif yang timbul apabila menikah pada usia di bawah 20 tahun, serta kurangnya pengetahuan tentang kesehatan reproduksi. Seorang perempuan yang mempunyai pengetahuan tentang reproduksi yang baik pasti akan lebih mempertimbangkan tentang hal usia pernikahannya karena mereka mengetahui apa saja akibat dari pernikahan usia dini terhadap reproduksinya.

\section{SIMPULAN}

1. Tingkat pengetahuan remaja putri tentang Pendewasaan Usia Perkawinan di SMPN 9 Kota Cirebon tahun 2019 masuk ke dalam kategori cukup (50\%).

2. Keseluruhan tingkat pengetahuan remaja putri tentang risiko Pernikahan Usia Dini di SMPN 9 Kota Cirebon tahun 2019 masuk ke dalam kategori cukup (40,6\%).

3. Terdapat hubungan yang berarti (signifikan) antara pengetahuan remaja putri tentang Pendewasaan Usia Perkawinan terhadap risiko Pernikahan Usia Dini di SMPN 9 Kota Cirebon tahun 2019.

\section{SARAN}

1. Bagi Responden, lebih meningkatkan pengetahuan tentang pentingnya Pendewasaan Usia Perkawinan agar tidak terjadi risiko yang disebabkan oleh pernikahan usia dini. Sehingga kelak tercipta keluarga kecil bahagia, sehat dan sejahtera.

2. Bagi Institusi Pendidikan, diharapkan dengan adanya penelitian ini agar ada jadwal khusus untuk diadakan penyuluhan perihal pendidikan kesehatan reproduksi remaja yang didalam nya terdapat materi perihal pendewasaan usia perkawinan dan risiko pernikahan dini.

\section{DAFTAR PUSTAKA}

1. Mubasyaroh. Analisis faktor penyebab pernikahan dini dan dampaknya bagi pelakunya. Yudisia: Jurnal Pemikiran Hukum dan Hukum Islam, 7(2), 385-411; 2016

2. Setyawan, Jefri, Rizka Hasna Marita, Ismi Kharin, Miftakhul Jannah. Dampak psikologis pada perkawinan remaja di Jawa Timur. Jurnal Penelitian Psikologi; 2016

3. Badan Pusat Statistik. Survey Sosial Ekonomi Nasional (SUSENAS) Maret 2017. Jakarta: Badan Pusat Statistik; 2017

4. Riset Kesehatan Dasar. RISKESDAS 2010. Jakarta: Badan Penelitian dan Pengembangan Kesehatan Kementerian Kesehatan RI; 2010.

5. Prihutomo, Sigit. Mencegah pernikahan anak melalui Program KKBPK. Seminar Nasional Kependudukan Banjarmasin.;2018

6. Sarwono, S. Psikologi remaja. Jakarta: PT. Raja Grasindo; 2011

7. Hasim, Wakhit. Praktik sosial dan alasan perkawinan anak di Cirebon. Skripsi. Cirebon: Fakultas Ushuluddin Adab dan Dakwah, IAIN Syekh Nurjati Cirebon; 2016

8. Notoatmodjo, S. Ilmu perilaku kesehatan. Jakarta: Rineka Cipta;2014

9. BKKBN. Pendewasaan usia perkawinan dan perlindungan hak-hak reproduksi bagi remaja Indonesia, cetakan ke-2. Jakarta: Direktorat Remaja dan Hak-hak Reproduksi Remaja;2010 
10. Andi Sjamsu Alam. Usia perkawinan dalam perspektif filsafat hukum dan kontribusinya bagi pengembangan hukum perkawinan Indonesia. Disertasi, Program Doktoral Universitas Gadjah Mada Yogyakarta; 2011.

11. Djamilah, Reni Kartikawati. Dampak perkawinan anak di Indonesia. Jurnal Studi Pemuda; 2014

12. Notoatmodjo, S. Metodologi penelitian kesehatan. Jakarta: Rineka Cipta;2012

13. Jahja, Y. Psikologi perkembangan. Jakarta: Kencana Prenada Media Group;2012

14. Stang EM. Faktor yang berhubungan dengan pernikahan dini di Kelurahan Pangli Kecamatan Sesean Kabupaten Toraja Utara. Jurnal MKMI; 2011 